\title{
Evaluation of the Seed-borne Nature of Bean Common Mosaic Virus (BCMV) in Cowpea
}

\author{
P. Aishwarya ${ }^{1 *}$, K. T. Rangaswamy ${ }^{1}$, S. Basavaraju ${ }^{2}$, Raghavendra Achari ${ }^{2}$, \\ Kedarnath Govin ${ }^{3}$, K. P. Rudraswamy ${ }^{4}$ and H. A. Prameela ${ }^{4}$ \\ ${ }^{1}$ Department of Plant Pathology, ${ }^{4}$ Department of Genetics and Plant breeding, \\ UAS, Bengaluru, India \\ ${ }^{2}$ Department of Plant Pathology, UHS, Bagalkot, India \\ ${ }^{3}$ ICAR, KVK, Dakshina Kannada, India \\ *Corresponding author
}

\section{A B S T R A C T}

\section{Keywords \\ Cowpea, BCMV, Seed transmission, Embryo and cotyledon, DAS ELISA}

\section{Article Info}

\section{Accepted:}

04 October 2020

Available Online:

10 November 2020

\begin{abstract}
Bean Common Mosaic Virus (BCMV) is an important viral disease in legumes, particularly the cowpea. It is a member of potyvirus, transmitted mechanically and by aphids in a non- persistent manner. Seed transmission results in the primary dispersal of the virus to new locations, often difficult to contain the spread of the virus. Hence seed transmission studies were carried out in cowpea variety C-152. It was determined by the grow out test at the two-leaf stage. The rate of seed transmission varied from 20-30 per cent in pot culture studies. Seed-borne nature of BCMV in cowpea was confirmed by DAS ELISA. Serological DAS ELISA of the cowpea seeds harvested from BCMV infected plants of both cultivars C-152 and $\mathrm{KBC}-2$ revealed the presence of BCMV in embryo and cotyledon, but not in the seed coat. However, the virus titre differed between cotyledon and embryo between both the cultivars.
\end{abstract}

\section{Introduction}

Cowpea [Vigna unguiculata (L.) Walp.] is an important legume crop with high protein content. It is a crop of tropics and subtropical regions grown in sub-Saharan Africa, Asia, Central and South America. It is used as food, fodder, green manuring and also as a vegetable crop. It is rich in carbohydrates, proteins with traces of iron and calcium. It is also a good source of essential amino acids like lysine, leucine and phenylalanine.
In India, it is grown as a minor crop in states of Punjab, Haryana, Delhi, and West UP, along with a considerable area in Rajasthan, Karnataka, Kerala, Tamilnadu, Maharashtra and Gujarat. Pests and diseases threaten the yield of legumes. In India, cowpea occupies an area of about one million hectare with an annual production of 2.24 million tonnes and average productivity of $570 \mathrm{~kg} \mathrm{ha}^{-1}$.

Cowpea is susceptible to fungal, bacterial and viral diseases to a greater extent along with 
insects. More than 140 viruses have been identified as naturally infecting cowpea (Hughes and Shoyinka, 2003). The major viral diseases are Cowpea Aphid-Borne Mosaic Virus (CABMV), Bean Common Mosaic Virus (BCMV), Cowpea Mild Mottle Virus (CPMMV), Cowpea Severe Mosaic Virus (CPSMV), Cowpea Mosaic Virus (CPMV), Cowpea Chlorotic Mottle Virus (CPCMV), Cucumber Mosaic Virus (CMV) and Cowpea Chlorotic Mosaic Virus (CCMV). Among them, BCMV is a major viral disease in cowpea resulting in significant yield losses to the tune of 70 per cent.

Reported major hosts of BCMV are Vigna unguiculata (mungbean), Arachis hypogaea (groundnut), Glycine max (soybean), Vigna angularis (adzuki bean), Vigna mungo (Taiwoand Gonsalves., 1982; Zhou et al., 2014).

BCMV is a positive single-stranded RNA and belongs to family potyviridae. It is transmitted mechanically naturally and artificially by sap inoculation. Insect vector relationship in BCMV transmission involves aphids (Aphis craccivora) in a non-persistent manner.

Seed transmission plays a vital role in the epidemiology of viral crop diseases. It helps in carrying the virus from one season to the next, long-distance transport of virus, and in providing foci of primary infection (Bashir and Hampton, 1996). Plants grown from infected seeds are usually stunted and unproductive. Plants infected later in the season by aphids or mechanical transmission usually have little loss in yield, but a high percentage of the seed harvested from such plants may be infected and should not be used for seed purpose (Gillaspie et al., 2007).

Disease outbreaks generally originate from contaminated seeds. Seed transmission in plant viral diseases is a major growing concern. It serves to be a primary source of inoculum of the virus. This results in transmission of the virus to new regions leading to secondary transmissions further. More viruses are transmitted through seeds of cowpea than any other crop species (Bashir, 1993). It is therefore desirable to develop an understanding of these viruses, particularly about seed-borne potyviruses. Hence seed transmission nature of BCMV was studied in controlled and field conditions in detail.

\section{Materials and Methods}

\section{Pot culture studies}

Cowpea plants of variety C-152 showing typical symptoms of BCMV were tagged in the field. Seeds were harvested from the infected plants and were grown in glasshouse in controlled conditions to determine the presence of BCMV in the seeds (Figure 2).

The leaves of the tagged plants showing BCMV symptoms were subjected to DAS ELISA (Double Antibody Sandwich Enzyme Linked Immunosorbent Assay) using BCMV specific antisera to confirm the virus to be BCMV (Table 1 and Figure 1)

\section{To ascertain seed-borne nature of the virus}

Seeds of the tagged plants were further soaked in water for four hours and later dissected into embryo, cotyledon and seed coat. The dissected parts of the seeds, along with whole seeds, were subjected to serological assays to know the exact location of the BCMV virus in the seed.

Healthy leaves and healthy seeds were taken as negative control and infected leaves of BCMV were taken as a positive control. Absorbance values were recorded at $405 \mathrm{~nm}$ using ELISA reader. 


\section{Preparation of buffer containing samples}

Whole seeds, dissected embryo, cotyledon and seed coat of two cowpea genotypes C-152 and $\mathrm{KBC}-2$ (Figure 3),infected leaf and seed samples, healthy leaf samples were ground in pestle and mortar with sample buffer in the ratio of 1:20.The ground samples were centrifuged at $8,000 \mathrm{rpm}$ for five minutes. The supernatant of the samples obtained was used for the detection of BCMV by ELISA.

\section{Detection of BCMV in cowpea by DAS ELISA}

BCMV was detected in cowpea samples using DAS ELISA technique by using an antiBCMV capture antibody and ALP labelled anti-BCMV detection antibody (Agdia, USA).

\section{Protocol}

The presence of virus in seed tissue was determined by performing the double antibody sandwich enzyme-linked immunosorbent assay (DAS-ELISA) using an Bean Common Mosaic Virus polyclonal antibody as per the manufacturer's protocol.

The capture antibody (Anti-BCMV) was diluted with carbonate coating (1:200) buffer before use. $100 \mu l$ of the prepared capture antibody was pipetted into each well. Coated plates were incubated overnight in the refrigerator $\left(4^{\circ} \mathrm{C}\right)$. After incubation, the wells were emptied into a sink or waste container. The test wells were filled completely with PBST and then quickly emptied again. This step was repeated twice.

BCMV infected and healthy plant tissue was ground separately using a mortar and pestle in PBS buffer at 1:20 ratio (tissue weight in g: buffer volume in $\mathrm{ml}$ ). The homogenate was transferred to a micro-centrifuge tube of 1.5 $\mathrm{ml}$ and centrifuged at $8,000 \mathrm{rpm}$ for 10 minutes. Following loading diagram, $100 \mu 1$ of clear supernatant was loaded into sample wells. In addition, $100 \mu \mathrm{l}$ of positive control was dispensed into positive control wells and $100 \mu 1$ of sample extraction buffer was loaded into buffer wells. Plates were kept inside the humid box and incubated for 2 hours at room temperature or overnight in the refrigerator (4 $\left.{ }^{\circ} \mathrm{C}\right)$.

After incubation, the plates were washed with PBST, as in step 5. The test wells were inspected for the presence of plant tissue. Enzyme conjugate (ALP labelled antiBCMV) supplied as concentrated solution was diluted (1:200) in PBS-TPO buffer and $100 \mu 1$ of enzyme conjugate solution was dispensed into test wells. Plates were kept inside the humid box and incubated for 2 hours at room temperature or overnight in the refrigerator $\left(4^{\circ} \mathrm{C}\right)$.

After incubation, the plates were washed with PBST, as in step 5.The substrate solution was prepared by dissolving each PNPP tablet (5 $\mathrm{mg}$ ) in $5 \mathrm{ml}$ of substrate buffer, at a concentration of $1 \mathrm{mg} / \mathrm{ml}$, about enough for five 8-well strips. $100 \mu \mathrm{l}$ of PNPP substrate was dispensed into each test well. Plateswere incubated in a humid box for 60 minutes. The test wells were examined by measuring on a ELISA plate reader at $405 \mathrm{~nm}$.

\section{Results and Discussion}

Among the various modes of transmission of viral diseases, seed transmission results in dissemination of the virus to new locations unknowingly. Hence it is very important to determine and confirm the seed transmission nature in of BCMV in cowpea.

The seeds harvested from the infected tagged plants of BCMV sown under glass conditions started to show typical symptoms of BCMV (Figure 2). The first symptoms of seed-borne 
infection appeared on cotyledonary leaves as fine vein clearing followed by mosaic mottling and vein banding on newly formed trifoliate leaves. The results are in conformity with the reports of Udayashankar et al., (2012); Puttaraju, et al., (2004); Sanjeev Reddy (1997); Bashir (1993); Sekar and Sulochana (1988) and Pavitra (2013).
The symptoms were visible at two-leaf stage of the crop, sown after seven to ten days in the pots. Seed transmission rates varied from 20-30 per cent respectively, in the variety C152. The presence of BCMV virus in the germinated seedlings was confirmed upon DAS ELISA of the leaves harvested at twoleaf stage using BCMV specific antisera.

Table.1 Absorbance values at $405 \mathrm{~nm}$ to detect the BCMV in virus infected leaves of cowpea

\begin{tabular}{|c|c|c|c|c|}
\hline Variety & Replications & Buffer (control) & Healthy leaves & BCMV Infected leaves \\
\hline \multirow{3}{*}{$\mathbf{C - 1 5 2}$} & $\mathbf{R}_{\mathbf{1}}$ & 0.100 & 0.119 & 0.698 \\
\cline { 2 - 5 } & $\mathbf{R}_{\mathbf{2}}$ & 0.110 & 0.124 & 0.732 \\
\cline { 2 - 5 } & $\mathbf{R}_{\mathbf{3}}$ & 0.106 & 0.120 & 0.715 \\
\hline & Mean & $\mathbf{0 . 1 0 5}$ & $\mathbf{0 . 1 2 1}$ & $\mathbf{0 . 7 1 5}$ \\
\hline
\end{tabular}

Table.2 Absorbance values at $405 \mathrm{~nm}$ to detect the BCMV in different parts of cowpea seed

\begin{tabular}{|c|c|c|c|c|c|c|c|c|c|}
\hline \multirow[t]{2}{*}{ Varieties } & \multirow[t]{2}{*}{ Replications } & \multirow{2}{*}{$\begin{array}{c}\text { Buffer } \\
\text { (Control) }\end{array}$} & \multirow{2}{*}{$\begin{array}{c}\text { Healthy } \\
\text { seed }\end{array}$} & \multicolumn{4}{|c|}{ Seed/Parts of seed from infected plant } & \multirow{2}{*}{$\begin{array}{c}\text { Healthy } \\
\text { leaf }\end{array}$} & \multirow{2}{*}{$\begin{array}{c}\text { Infected } \\
\text { leaf }\end{array}$} \\
\hline & & & & $\begin{array}{c}\text { Whole seeds } \\
\text { of infected } \\
\text { plant }\end{array}$ & Embryo & Cotyledon & $\begin{array}{l}\text { Seed } \\
\text { coat }\end{array}$ & & \\
\hline \multirow{4}{*}{ C-152 } & $\mathbf{R}_{1}$ & 0.100 & 0.120 & 0.432 & 0.532 & 0.462 & 0.130 & 0.124 & 0.751 \\
\hline & $\mathbf{R}_{2}$ & 0.115 & 0.116 & 0.420 & 0.562 & 0.445 & 0.115 & 0.129 & 0.749 \\
\hline & $\mathbf{R}_{3}$ & 0.119 & 0.124 & 0.449 & 0.502 & 0.479 & 0.135 & 0.119 & 0.786 \\
\hline & Mean & 0.111 & 0.120 & 0.434 & 0.532 & 0.462 & 0.121 & 0.124 & 0.762 \\
\hline \multirow[t]{4}{*}{ KBC-2 } & $\mathbf{R}_{1}$ & 0.119 & 0.118 & 0.507 & 0.425 & 0.533 & 0.120 & 0.130 & 0.691 \\
\hline & $\mathbf{R}_{2}$ & 0.112 & 0.120 & 0.510 & 0.409 & 0.510 & 0.116 & 0.127 & 0.681 \\
\hline & $\mathbf{R}_{3}$ & 0.110 & 0.116 & 0.504 & 0.441 & 0.556 & 0.124 & 0.133 & 0.701 \\
\hline & Mean & 0.113 & 0.118 & $\mathbf{0 . 5 0 7}$ & 0.425 & 0.533 & 0.120 & 0.130 & 0.691 \\
\hline
\end{tabular}

Fig.1 ELISA based detection of BCMV infecting cowpea



B: Buffer, H: Healthy leaves and I: Infected leaves 
Fig.2 Seedlings raised from seeds harvested from BCMV infected plants showing symptoms of the virus

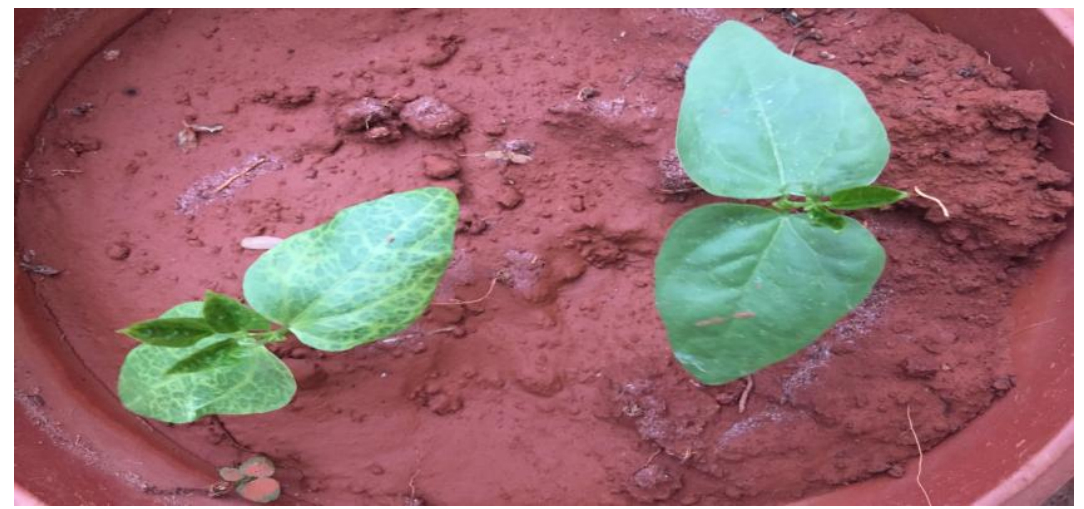

Fig.3 Dissected Cotyledon, seed coat and embryo, of cowpea used for ELISA

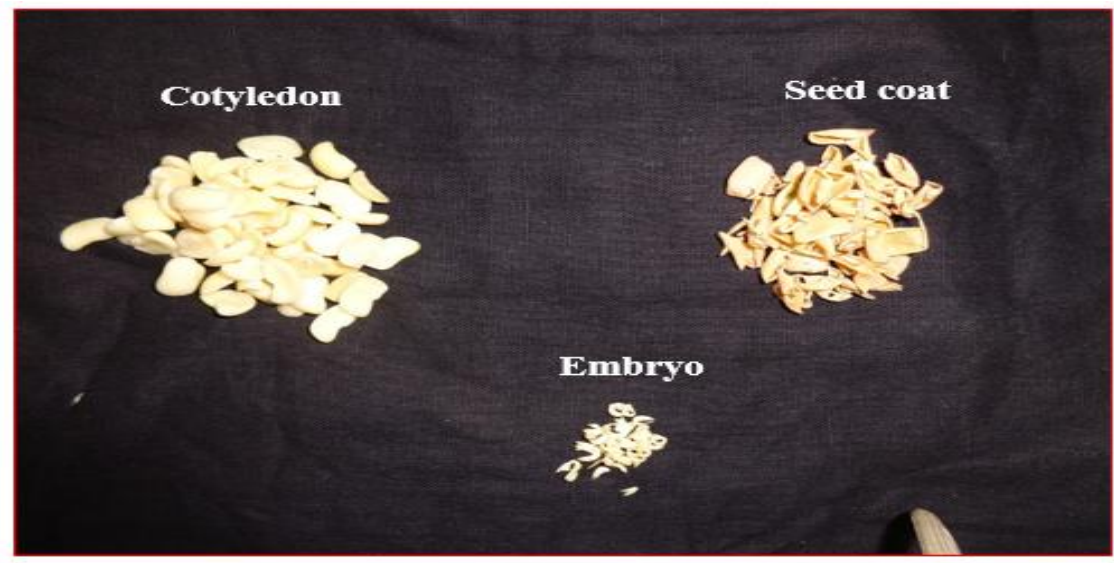

Fig.4 Serological detection of BCMV in different parts of cowpea seeds by DAS ELISA. (B1, B2: Buffer, W1, W2: Whole seeds, E1, E2: Embryo, C1, C2: Cotyledon, SC1, SC2: Seed coat, HS1, HS2: Healthy seed, HL1, HL2: Healthy leaf, I1, I2: Infected leaf)

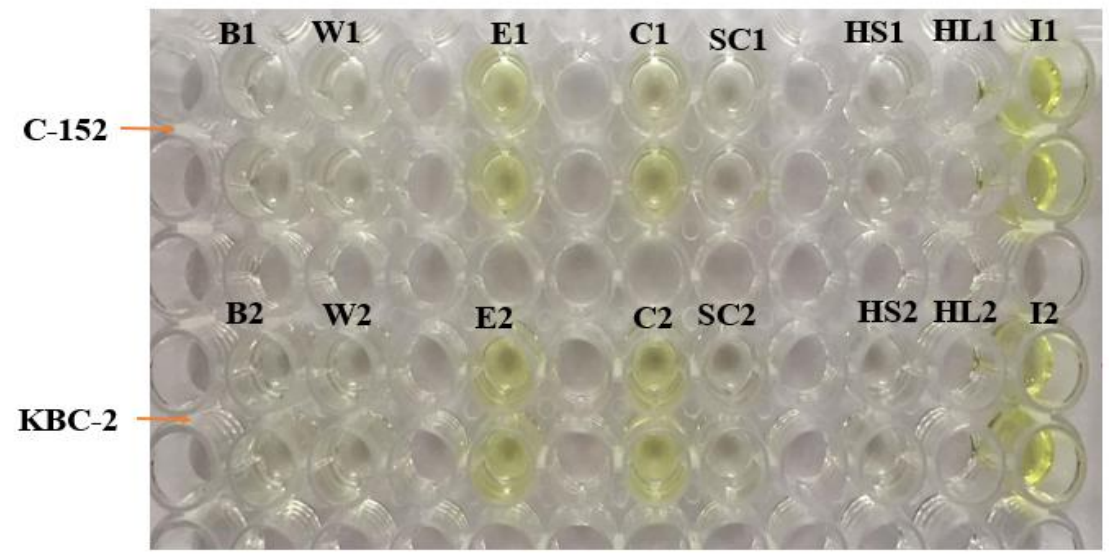


Grow out test of the infected harvested seeds showed the presence of the virus. Pot culture studies indicated the BCMV to be seed-borne in nature. Further studies were carried over to know the location of the virus in the seed. The seeds dissected into embryo, cotyledon and seed coat along with the whole seeds were subjected to DAS ELISA (Figure 3). To check the varietal difference regarding seed transmission, along with $\mathrm{C}-152$, variety $\mathrm{KBC}$ 2 was also subjected to DAS ELISA.

Table 2 showed the absorbance values in the whole seeds of the infected plants of both the cultivars was around four times more compared to the healthy seeds taken as negative control. Absorbance values of embryo, cotyledon of both the cultivars showed values that was found to be four to five times more compared to negative control of healthy leaves and healthy seeds.

But the absorbance values of seed coat in both the cultivars was almost on par with negative control of healthy leaves and seeds. Similarly, between healthy and infected leaves, absorbance values of infected leaves was around six times the buffer control in KBC-2 whereas, around seven times the buffer control in C-152 (Table 2 and Figure 4).

DAS ELISA confirmed the presence of virus in the embryo and cotyledon and the absence of virus in the seed coat. Serological studies confirmed the virus to be internally seedborne in nature. Further, the presence of the virus was seen in both the cultivars. It was found in the whole infected seeds, embryo and cotyledon but absent in the seed coat. But the absorbance values differed between the two cultivars (Table 2 and Figure 4). This indicated the virus concentration also depends upon the different cultivars. The results are in accordance with the reports of Ojuederie et al, (2009), Puttaraju et al., (2004), Bashir and Hampton (1996).
In conclusion the BCMV in cowpea results in significant yield losses. This increases further with different modes of transmission. Seed transmission plays a significant role in the disease epidemiology. Henceforth the detection of BCMV in seed in view of seed quality control assumes a great importance. The pot culture and serological studies confirmed the seed borne nature of BCMV in cowpea. This helps in early rouging of disease plants to prevent the transmission. Further the harvested seeds of cowpea can be tested for the presence of the virus through random sampling, to confirm the seed lot, to be free of virus.

\section{Acknowledgements}

I would like to express my gratitude to my mentor Dr. K. T Rangaswamy for his immense guidance. I would also thank Dr. S Basavaraju, Dr Raghavendraachari, Dr. S. Ramesh, Dr. H.S Jagadeesh, Dr. K.P Rudraswamy and Mrs. H. A. Prameela. I am grateful to my Dept. of Plant Pathology and ZARS, UAS, GKVK, Bengaluru.

Conflict of interest: Authors don't have any conflict of interest

\section{References}

Bashir, M. and Hampton, R. O. 1996, Detection and identification of seedborne viruses from cowpea (Vigna unguiculata L. Walp.) germplasm.Pl. Pathol., 45: 54-58.

Bashir, M. 1993, Serological and biological characterization of seed-borne isolates of blackeye cowpea mosaic and cowpea aphid-borne mosaic potyviruses in Vigna unguiculata L. Walp).PhD Thesis, Pakistan J. Agril.Sci., 247.

Gillaspie, A. G. 2007, Attempts to improve the method of screening cowpea germplasm for resistance to cucumber 
mosaic virus and Blackeye cowpea mosaic virus. Pl. Pathol. J., 6(2): 202205.

Hughes, J. D. A. and Shoyinka, S. A. 2003, Overview of viruses of legumes other than groundnut in Africa in plant virology in sub-Saharan African, Proc Plant Viro., 553-568.

Ojuederie, O. B., Odu, B. O. andllori, O. 2009, Serological detection of seed borne viruses in cowpea regenerated germplasm using protein a sandwich enzyme linked immunorsorbent assay. African Crop Sci. J., 17(3): 125-132.

Pavitra, B. S. 2013, Molecular detection and identification of virus causing mosaic disease on cowpea (Vigna unguiculata L. walp). MscAgri, Thesis, Univ.Agril.Sciences, Bengaluru, pp131.

Puttaraju, H. R., Prakash, H. S. and Shetty, H. S. 2004, Seed infection by Blackeye cowpea mosaic potyvirus and yield loss in different cowpea varieties. J. Mycol. Pl. Pathol., 34: 41-46.

Reddy, S. H. 1997, Characterisation and serio diagnosis of a cowpea Vigna unguiculata (L.) Walp. mosaic virus. M.Sc. (Agri). Thesis, Univ. Agric. Sci.,
Bangalore, pp 88.

Sekar, R. and Sulochana, C. B. 1988, Blackeye cowpea mosaic virus occurrence in India. Indian $\mathrm{J} . \mathrm{Pl}$. Pathol., 1: 38-44.

Taiwo, M. A. and Gonsalves, D. 1982, Serological groupings of isolates of black eye cowpea mosaic and cowpea aphid-borne mosaic viruses. Phytopathol., 72: 583-589.

Udayashankar, A. C., Nayaka, S. C., Kumar, H. B., Shetty, H. S. and Prakash, H. S. 2012, Detection and identification of the Blackeye cowpea mosaic strain of Bean common mosaic virus in seeds of cowpea from southern India. Phytoparasitica, 37: 283-293.

Zhou, G. C., Wu, X. Y., Zhang, Y. M., Wu, P., Wu, X. Z., Liu, L. W., Wang, Q., Hang, Y. Y., Yang, J. Y., Shao, Z. Q., Wang, B. and Chen, J. Q. 2014, A genomic survey of thirty soybeaninfecting Bean Common Mosaic Virus (BCMV) isolates from China pointed $\mathrm{BCMV}$ as a potential threat to soybean production. Virus Res., 191: 125-133.

\section{How to cite this article:}

Aishwarya, P., K. T. Rangaswamy, S. Basavaraju, Raghavendra Achari, Kedarnath Govin, K. P. Rudraswamy and Prameela, H. A. 2020. Evaluation of the Seed-borne Nature of Bean Common Mosaic Virus (BCMV) in Cowpea. Int.J.Curr.Microbiol.App.Sci. 9(11): 239-245. doi: https://doi.org/10.20546/ijcmas.2020.911.028 